\title{
NECESSITY OF INDUSTRIAL ARBITRATION
}

\author{
By Rabbi Joseph Krauskopf, D.D., \\ Philadelphia.
}

We must leave it to demagogues or to pre-election politicians to deliver themselves of fulsome panegyrics on the dignity of labor, and on the blessings conferred upon society by the laboring man. It would be wasting time to dwell upon what is one of the best known and best appreciated truths of human knowledge. More than waste of time it would be to show how capital and labor are but as the two blades of a pair of scissors, each useless without the other-facts so well known and so profoundly appreciated by people of intelligence, that, to speak of them were to insult the reader's intelligence.

An equal waste of time it would be to enter upon a discussion on the benefits of capital to civilized society, and on the necessity of its protection, for every railroad that traverses our continent, every ship that plows the deep, every factory and mill, every forge and furnace, every university and library, every school and art gallery, every invention that lessens the hardship of labor, and every comfort that heightens the joy of life, speak of the blessings of capital with a wisdom and an eloquence, such as even the most learned writer on economics or the most eloquent orator cannot reach. Starting, therefore, with these axiomatic truths of economics as our basis, it is to be hoped that, if anything be said in the development of this article which may seem harsh to either capital or labor, it is not to be charged to prejudice or ignorance.

That something is to be said must be evident even to the superficial observer. There exists a state of war between capital and labor. There is bitter conflict in some quarters; there is menacing hostility in others. Employer and employee stand arrayed against each other with gauntleted hands. Strong leagues are compacted; open and secret alliances are formed. Campaigns are being carried on in trade-papers and on platforms; bitter incriminations and recriminations are published in lurid type. Pictorial art is resorted to to inflame the mind. Capital is represented as a Moloch, grow. 
ing fat on the heart's blood of the poor; and labor is shown as an anarchist whose sole aim is the crushing of the labor-giver. The two, who in the economic household are as closely bound together as are husband and wife in domestic life, and who should live peacefully side by side, promoting each others good and fur hering the highest ends of society, are engaged in a bitter struggle.

The cause of the contention between the two is largely TradeUnionism. Each believes that it has right on its side, and, listening to the story of each, the uninformed is at a loss to tell why there should be the slightest contention between the two. Turn to Mr. John Mitchell's book entitled "Organized Labor," and you read: "Labor unions are for the workman, but against no one. They are not hostile to employers, not inimical to the interests of the great public. . . . There is no necessary hostility between labor and capital. Neither can do without the other. . . . The interest of the one is the interest of the other, and the prosperity of the one is the prosperity of the other. . . . Trades-unionism has justified its existence by good works and high purposes. At one time viewed with suspicion by workman and employer alike, it has gained the affections of the one and the enlightened esteem of the other. . . . It has improved the relations between the employer and employed. . . . The labor union is a great, beneficent, democratic institution, not all-good, not all-wise, not all-powerful, but with the generous virtues and enthusiastic faults of youth. . . . The trade agreement makes for peace in the industrial world."

Turn to the book entitled "Some Ethical Phases of the Labor Question," by Carroll D. Wright, late United States Commissioner of Labor, and after reading of the miseries and hardships of labor, prior to the introduction of the modern factory system, made possible by capital, you hear his verdict: "Better morals, better sanitary conditions, better health, better wages-these are the practical results of the factory system as compared with that which preceded it." You inquire of the heads of large industrial establishments, and they tell you of the well-equipped sanitary shops and factories and mills, of the many provisions that have been made to lessen the drudgery of toil by means of labor-saving machinery, of the comforts that have been introduced, such as lunch-rooms, wash-rooms, reading-rooms, and the like; of the improved dwellings that are furnished 
to employees, and of the opportunity that is afforded them for mental, moral and spiritual culture. You question some recently arrived laborers, and they tell you of the starvation wages they received in the old world, of the starvation food on which they subsisted, of the long hours of labor that were required of them, of the miserable homes in which they lived, of the hard labor that was exacted of their wives, even of their children, to enable their families to eke out an existence.

After listening to such highly-colored accounts of the attitude of the employer and employee toward each other, what could be more natural than to conclude that the most harmonious relationship exists between the two? But we have heard also the other story. We know that employers deny the professions of peacefulness made by the trade-unions, and employees declare that they see no sign of the good-will pretended by the employers, that they pay in toil twice and thrice for whatever little they get. The one side claims that trade-unionism has but the enslavement and ruination of capital for its goal, or, at best, that its object is, as President Eliot, of Harvard University, expressed it, "to work as few hours as possible, to produce as little as possible during that time, and to receive as much as possible for the service given."

A Damoclean sword, says the labor-giver, hangs suspended over him on the slenderest kind of thread, ready to drop upon him at the merest word or beck of labor-leaders. He can never tell when his industry may be brought to a standstill or crippled. His laborers' contract with him may be never so binding, his treatment of them may be never so considerate, let the labor leader command his men to strike out of sympathy with strikers in some other establishment or industry, and out they step, utterly unmindful of the binding nature of their contract, and of the considerate treatment they have received.

Scarcely is one fight over when another is begun. Mr. Brooks, author of "The Social Unrest," relates that after the recent strikes in the hard coal regions, an employer said to him, "I have been in this business more than twenty-five years, and it seems to me that I have been in the strike business rather than in the coal business." Within the past twenty-five years there have been more than three thousand strikes in the coal industry alone. Mr. Brooks also tells that after the miners had won their strike of Ig00, some of the 
companies began to put stockades about their breakers. Upon his asking why they did this, seeing that it was a time of peace, one of them replied, "Oh, we shall soon enough have another fight, and we propose to be ready for it. To make concessions to a tradeunion means a fight at the end."

This seems to be the opinion of employers in general. There is no living in peace, says an employer, with labor agitators. There is no tyranny like unto theirs. A non-union man, has, in their eyes, no more right to life and liberty and protection than if he were the worst of criminals. It is widely claimed that these labor agitators look far more to their own interests than to those of the laboring man. To hold on to their lucrative positions, they feel, it is claimed, that they must make a show at doing things, and their only way of cloing things is to create trouble between employer and employee. Now the hours are too long, now the wages are too small. Now the number of men employed is too little, now the machinery in use is too much. Now the efficient non-union man employed must be dismissed, now the inefficient union man must be retained. They little care whether or not they kill the goose that lays the golden egg. They little consider the poor laboring man upon whom a long-enduring strike bears the hardest. They little care whether by closing to the laborer the doors of industry, they open wide to him the doors of want and misery.

It is bad enough, employers say, that labor leaders should know of no other way for reconciling difficulties between employers and their men than by a strike. But to call out from other shops the men who have no grievances, who are under contract, who are satisfied with wages and hours and treatment, to call these out for no other reason than to use them as a sort of a thumb-screw on the employer in whose place the strike has occurred, is an outrage beyond endurance. It places the reins of industrial authority entirely in the hands of the labor leader. It places the owner of the establishment in the attitude of a dependent on the good will of a dictator. Employers ask themselves: what if they were to do as they are done by, by their employees? What, if notwithstanding contracts, they were to shut out their men because of sympathy with that fellow employer in whose establishment a strike has occurred? What an outcry the laboring people would raise! 
The injustice against which they would cry out, and justly, would be precisely the same which they themselves constantly commit.

Little wonder that employers should be disheartened or bitterly incensed, or that they should refuse to confer with people who behave like highwaymen. Little wonder that they should refuse to enter into contracts with people to whom a contract is of no more value than the paper it is written on. Little wonder that employers should become indifferent to the lot of their employees, when for all the pains they have taken, and all the means they have expended to provide them with comforts so as to make labor agreeable, and environment pleasant, they have but base ingratitude for their reward. Little wonder that in the gigantic shops which Carnegie built up, and in which he at one time welcomed the Union as "beneficial both to labor and capital," there should be a feeling to-day against the Union so pronounced, as to lead one of the strongest men of the company to declare, that they would use every resource within their reach rather than have a trace of unionism in their shop.

Sad as are the plaints of the employers those of the employees are sadder still. They admit that their measures are frequently harsh, but, they claim, there are no others at their command to enforce their rights. When weakness fights against strength, poverty against wealth, the ends sought must be considered, they say, and not the means employed. It is a fight for existence and not for sport. It is a fight for their wives and children, for food to still their hunger, for clothes with which to cover their nakedness, for the ordinary comforts with which to make existence tolerable. That they themselves may not be crushed, they must crush the power arrayed against them. They must meet force with force, they say, tyranny with tyranny. Labor, being their only commodity, and capital desiring to amass by means of it yet greater wealth, they must place the highest possible value upon it. Capital, they claim, is the enemy of society. It corrupts the law and uses it for the oppression of the poor. But for the laboring man's combination with his fellow laboring man, his lot, they claim, would still be that of the slave or serf, his wages would still be a mere pittance, his hours of labor twice as long as now, his home a hovel, his clothes rags, his degradation as base as in the days now happily past. It is only by uniting all the laboring men, by making the interest of one the interest of 
all, that they hope to cope successfully with the mighty power of capital, and obtain the rights and the rewards that belong to labor. Having these noble ends in view, they claim they have a perfect right, in mere self-protection, to coerce the non-union man into the union, and to brand as a "scab" him who is so blind or base as not to see that his own best good lies in strengthening the hand of his fellow sufferers.

Being part creators of wealth, they are tired, they say, of seeing all the good things of life going to the rich and all the undesirable things to them. It is galling to them to know that one per cent of the population of the United States owns more wealth than the remaining ninety-nine per cent, and that the laboring people, who constitute eighty-eight per cent of the population, own but thirteen per cent of its wealth. It is galling for them to read and hear of the extravagances going on in society, and to feel that it is their labor which is paying for it all, while they themselves are often lacking the necessities of life.

They admit that their wages are higher than they ever were before, and their hours shorter and their homes better, but, they claim, their demands are higher, and that the means of existence are far more expensive than they were. With all their higher wages, they ask, what is the lot of most of the laboring men but misery? The slums and crowded tenement districts are the homes of most of the laboring people. If wages are fair the number of working days in the year are short. On an average, about half of the year, they claim, is spent by the working people in enforced idleness. Life for most of them is a hand-to-mouth existence. Only few of them can lay by anything for old age. The casualities they meet with are many; the death rate is large; disease is frequent. If sick for any length of time, the charities must help them out. If old and feeble they must seek refuge in the almshouse. Money trusts and operators' combines, they say, exist solely for the purpose of crushing every labor union and of stamping out every right and liberty of the laboring man.

If the latter claim be the aim of employers, they will never succeed. The progress of evolution is forward and upward. The slave rose into the serf, the serf into the free man, and no trust and no combine, nor all of the trusts combined will ever suc- 
ceed in degrading the American laboring man back again into slavery, or even into serfdom. The recognition of his rights has been purchased at too dear a price to be surrendered without a bitter struggle.

There is certainly no gainsaying that laboring men have a legal and moral right to organize unions for self-protection and selfimprovement. There was a time when master and man worked side by side at the loom, or at the shoemaker's bench, or in the wagon shop, and when the employee had no difficulty to reach the ear of the employer, for the righting of wrongs, for the lessening of hours or for the increase of wages. But, modern expansion of industries has created new conditions and presents new problems. The individual is lost in the corporation; the owner is replaced by foremen, bosses, managers, superintendents, directors.

Capital deals in representative capacity, and labor is obliged to do the same. It must have its representatives to protect its rights. It is with the same end in view that we organize government. Individuals combine and select a councilman to represent them in municipal government; a legislator in state government, a congresman in national government. Union and representation are American principles; they are the very foundation of our liberties, and must have sacred recognition by every freedom-loving American.

Next to the right of representative union, laboring men are entitled to an adequate share of the profits of labor. It is certainly unjust that the lion's share should fall to capital, while labor, the equal producer of it, should be obliged to content itself with the pickings; that the one, from the profits of capital, should be enabled to riot in luxury and to revel in extravagance, while the other, from the product of labor, should be barely able to keep body and soul together. Next to the right to adequate wages, the laborer has a right to reasonable hours of work. It is wrong to place human flesh in competition with steam and machinery. If modern industrial life cannot leave to the laborer the privilege of breaking off his day's task whenever he chooses, the laborer, in return, must be guaranteed no longer hours of toil than is consistent with the needs of health, with the obligations toward his family, with the duties he owes to his self-government.

Moreover, the laborer has rights to be protected against being "blacklisted," when exercising his inalienable privilege of selling 
his labor to whomsoever he chooses. When seeking employment, he has the right not to be discriminated against for being a member of a trades-union. He has the right of uniting with his fellow laborers in peacefully quitting work, if his demand for higher wages or lesser hours, or his request for righting certain real or imaginary wrongs be not complied with.

All these rights the laborer has, and all these rights every loyal American and lover of humanity sacredly honors. But when the trades-union passes beyond these rights, and invades the territory of the employer, when it arrogates to itself the right to rum the employer's business, the right to dictate to the employer, how much wages he may and may not pay, from whom he may and may not buy, and to whom he may and may not sell, how many hours he may and may not work, how many machines he may run, and at what speed, how many apprentices he may and may not employ, when it undertakes to cripple the employer's industry by calling out his men, because of sympathy with other strikers, or because of his employing non-union men, by boycotting his wares, by sending out its pickets to waylay non-union men, and to force them by intimidation or violence either to leave work or to join the union, it is then that the trades-union becomes an organized tyranny, and the union man a despot. It is then that a state of war exists between employer and employee, and that, in retaliation, capital resorts to drastic measures that are no less reprehensible.

I will grant that it is irritating to see men ready to take the place vacated because of insufficient pay, or because of too many hours of work, or because of some other grievance, and I can see every reason why such people should be peaceably reasoned with, and, if possible, made to join the union. But to set upon such men, when argument fails, to assail them, to endanger their lives, to persecute their families and those that have relations with them. yea, even to burn or dynamite their homes, or to club or shoot them to death-and not only them but officers of the law, delegated by the city or the state to protect them, in the lawful discharge of their rights-such procedure is a degree of lawlessness nothing short of anarchy, and demands the most condign penalty of the law.

It is lawlessness when a trade-11nion regards itself above the authority of the law of the land, and makes rules and regulations in contravention thereof. It is lawlessness, when a trades-union 
constitutes itself a governing agency, and claims authority to control those who have refused to join its ranks and to consent to its government, and to deny to them the personal liberties, which are guaranteed to every citizen by the constitution and the laws of the land. It was Abraham Lincoln who said "No man is good enough to govern another man without that other's consent." It is lawlessness to bring privations and suffering upon an unoffending community because of a want of commodity which non-union men are ready to furnish, but which union men will not permit under the threat of violence.

It is lawlessness to boycott the produce of a manufacturer, who has incurred the ill-will of a trades-union, and to extend the anathema to every trader who handles such boycotted goods, even to consumers who purchase them. It is not an inapt comparison to liken the boycott to the ecclesiastical ban. As there was no more cruel weapon during the Dark and Middle Ages than the ban to bring refractory individuals to the feet of the church, so does the modern industrial world, know of no more cruel weapon than the boycott, used by the trades-union, to bring under its yoke employers who persist in the belief that they have a right to manage their own affairs.

The cry of the people who are not direct participants in the controversy is as loud as is that of employer and employee. Though in no way responsible for the bitter feelings existing between the contending parties, they are made to suffer a large part of the consequences. If the strike ties up or cripples a public utility, the people are put to no end of inconvenience and alarm and loss. Lives of innocents are slaughtered. Properties are dynamited. The peace of the community is demoralized. The usual routine of life is broken up. The public places of instruction and amusement are closed. People in poor health collapse under the nervous tension of constant fear and fright.

Recognizing right in the contentions of employers and employees, the people believe that a way out of the difficulty ought to be found, must be found, for the sake of the general peace and good will. As government has provided courts for settling other quarrels between man and man, so must it provide courts for arbitrating differences that are arising in increasing numbers, and that 
are bound to arise in larger numbers, owing to the growing discontent among laboring people, and owing to the constant inflow of immigrants, who, being in need of employment, are bound to compete in the open market for the labor to be had. More and more the people feel that, as they have the right to call in the police when disturbances of the peace are annoying or endangering the neighborhood, or when they wish to have a nuisance abated in their immediate environment, so have they the right, in self-protection, and for the sake of the public peace, to demand that special courts be permanently established for the arbitration of industrial quarrels.

In that call for arbitrating our industrial conditions lies our hope for the future. It is a new cry and a far different one from that which follows reports of bullets and explosions of dynamite. It is this far-spreading demand for arbitration that gives a silver lining to the dark cloud that now lowers over us. That cry has already been answered in Germany, in Canada, in Australia, in New Zealand. Wherever answered, it has tempered much bitterness. The establishment of more than four hundred permanent courts of arbitration for trade disputes in Germany has lessened the number of strikes in that country to an astounding degree. Seventy per cent of the disputes in Germany between employer and employees have been brought before these tribunals, and although there is no obligation to accept the decisions rendered, with scarcely any exception, they are cheerfully accepted by the contending parties, and faithfully followed.

May we, too, soon learn this needed lesson. May we, too, soon learn that there are nobler and surer ways of settling trade disputes than by wars against classes by strikes and lockouts, by bullets and by bombs, by intimidation of employers and by starvation of employees. May we, too, soon see established in our midst the arbitration courts which Germany, across the Atlantic, Australia and New Zealand, in the Pacific, and Canada, our neighbor, have found a blessing to employer and employee and people. Arbitration courts are our only hope for industrial peace. Ours is the solemn duty to turn that hope into reality. 